\title{
Chapter 10 \\ Effect of Relaxin-Like Gonad-Stimulating Substance on Gamete Shedding and 1-Methyladenine Production in Starfish Ovaries
}

\author{
Masatoshi Mita, Yuki Takeshige, and Masaru Nakamura
}

\begin{abstract}
As in lower vertebrates, starfish oocyte maturation and ovulation are induced by a hormonal substance. Gonad-stimulating substance (GSS) is the first mediator in inducing these maturation and ovulation. GSS secreted from the nervous system acts on the ovary to produce 1-methyladenine (1-MeAde) as a maturation-inducing hormone. 1-MeAde induces germinal vesicle breakdown (GVBD) and follicular envelope breakdown (FEBD), releasing the oocyte from the ovaries, that is, spawning. Recently, GSS was purified from the radial nerves of the starfish Asterina pectinifera and its chemical structure was determined to be a relaxin-like peptide. To further elucidate the physiological roles of GSS on oocyte maturation and ovulation, this study examined the effect of synthetic GSS on 1-MeAde production in intact ovaries, folliculated oocytes, isolated follicle cells, and spawned ovaries containing follicle cells of the starfish (sea star) A. pectinifera. Spawning was induced by synthetic GSS as a dosedependent manner. However, a high concentration of GSS failed to induce spawning. 1-MeAde production in an ovarian fragment also declined at a high concentration of GSS. Similar dual effects of GSS were observed in folliculated oocytes. In contrast, 1-MeAde production in isolated follicle cells and spawned ovaries did not decrease at a high concentration of GSS. Interestingly, egg jelly inhibited GSS-induced 1-MeAde production in follicle cells. These results may suggest that egg jelly disturbs GSS action on 1-MeAde production and spawning in ovaries.
\end{abstract}

Keywords 1 -Methyladenine $\bullet$ Egg jelly $\bullet$ Gonad-stimulating substance $\bullet$ Spawning - Starfish

M. Mita $(\triangle) \cdot$ Y. Takeshige

Department of Biology, Faculty of Education, Tokyo Gakugei University,

Tokyo 184-8501, Japan

e-mail: bio-mita@u-gakugei.ac.jp

M. Nakamura

General Research Center, Churashima Foundation, Ishikawa 888, Motobu-cho,

Kunigami-gun, Okinawa 905-0206, Japan 


\subsection{Introduction}

In most starfish, fertilization occurs in seawater, outside the female's body. A ripe ovary contains a huge number of fully grown oocytes of almost equal size. Each oocyte still possesses a large nucleus (germinal vesicle), which is arrested in late prophase of the first maturation division. The oocyte is surrounded by a single follicular layer. The follicles adhere firmly to each other and to the ovarian wall (Kanatani and Shirai 1969). Resumption of meiosis in immature oocytes and spawning from the ovary are induced by 1-methyladenine (1-MeAde) (Kanatani et al. 1969). 1-MeAde is produced by ovarian follicle cells on stimulation by gonad-stimulating substance (GSS) released from radial nerves (Kanatani 1985). However, the action of 1-MeAde is indirect; it acts on the oocyte membrane receptor (Yoshikuni et al. 1988; Tadenuma et al. 1992) to activate a cytoplasmic maturation or M-phase promoting factor (MPF) (Okumura et al. 2002; Hiraoka et al. 2004), which is the direct trigger of germinal vesicle breakdown (GVBD) (Kishimoto and Kanatani 1976) and follicular envelope breakdown (FEBD) (Kishimoto et al. 1984). Once FEBD occurs, the denuded oocytes become freely movable within the ovary and are forced out by contraction of the ovarian wall (Shirai et al. 1981).

Previous studies have shown that an inhibitor of spawning, "shedhibin," is contained in the nerve extract (Cheat 1966a, b). However, crude GSS inhibits spawning at a high concentration (Kanatani and Shirai 1970). Recently, GSS was purified from the radial nerves of the starfish Asterina pectinifera and its chemical structure was determined to be a relaxin-like peptide (Mita et al. 2009). In this chapter, hormonal action of GSS on spawning is described from the aspect of 1-MeAde production within ovaries.

\subsection{Effect of GSS on Spawning in Ovarian Fragments}

Starfish (the sea star Asterina pectinifera) were collected from several locations in Japan in the breeding season. An experiment was carried out to examine the effect of synthetic GSS on spawning. Ovarian fragments were placed in modified van't Hoff's artificial seawater (ASW) at $\mathrm{pH} 8.2$ containing synthetic GSS at various concentrations. After $1 \mathrm{~h}$ incubation at $20^{\circ} \mathrm{C}$, spawning was induced by GSS at concentrations exceeding $0.2 \mathrm{nM}$ GSS (Fig. 10.1). The median effective concentration $\left(\mathrm{EC}_{50}\right)$ was obtained with about $0.5 \mathrm{nM}$ GSS. However, GSS-induced spawning decreased at concentrations above $10 \mathrm{nM}$, and above $20 \mathrm{nM}$ GSS failed to induce spawning. These oocytes within the ovary were matured in a high concentration of GSS. It appears that GSS at a high concentration acts in some toxic way on the ovarian wall to inhibit its contraction, resulting in failure of spawning. 


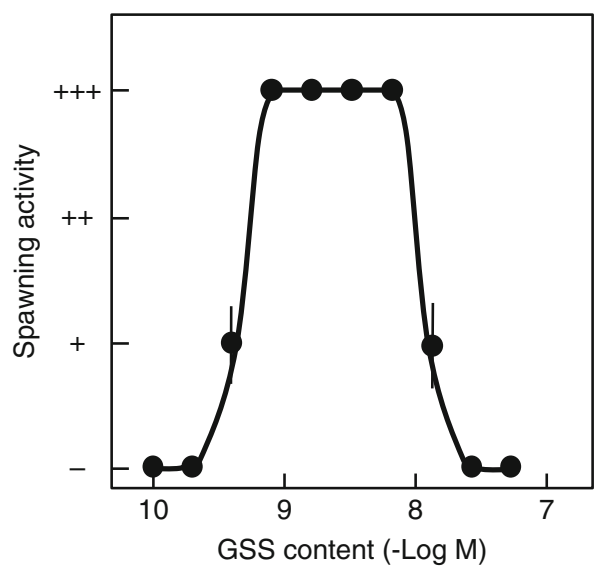

Fig. 10.1 Effect of gonad-stimulating substance (GSS) on gamete shedding from ovaries in starfish Asterina pectinifera. Ovarian fragments were placed in artificial seawater (ASW) containing GSS at concentrations indicated. After $1 \mathrm{~h}$ incubation at $20^{\circ} \mathrm{C}$, the sample was examined to determine whether spawning had occurred. (+++), spawning occurred and most oocytes matured; (++), about $50 \%$ oocytes matured; (+), a few oocytes were matured; and (-), no spawning occurred. Values are mean \pm SEM of four separate assays using different animals

\subsection{Effect of GSS on 1-MeAde Production}

Because GSS mediates oocyte maturation by acting on the ovary to produce 1-MeAde (Kanatani et al. 1969), we tested the action of synthetic GSS on 1-MeAde production in the whole ovary. When ovarian fragments of A. pectinifera were incubated in ASW containing synthetic GSS at various concentrations, the 1-MeAde produced was found in the incubation medium. The amount of 1-MeAde produced increased as the GSS concentration was raised, and reached maximum at $2 \mathrm{nM}$ GSS (Fig. 10.2a). However, it declined at concentrations above 2 nM GSS. In contrast, GSS-induced 1-MeAde production in isolated follicle cells increased in a dosedependent manner and reached a plateau at concentrations above $2 \mathrm{nM}$ GSS (Fig. 10.2b), which agrees with previous reports (Mita et al. 1987, 2009). Because GSS stimulates follicle cells as a target in starfish ovaries (Hirai and Kanatani 1971; Hirai et al. 1973), it is possible that unknown matter within the ovaries affects GSS action on follicle cells to produce 1-MeAde.

The ovaries in starfish A. pectinifera are filled with immature oocytes, each surrounded by an envelope consisting of follicle cells (Fig. 10.3a). Following treatment of ovary with 1-MeAde, not only GVBD but also FEBD occurs, and denuded maturing oocytes are spawned from the ovary. The follicle cells become clustered within the ovaries (Mita and Nakamura 1994). After spawning, follicle cells exit the ovaries. Thus, we examined the effect of GSS on 1-MeAde production in the spawned ovaries. Following incubation of the spawned ovaries with GSS at various 

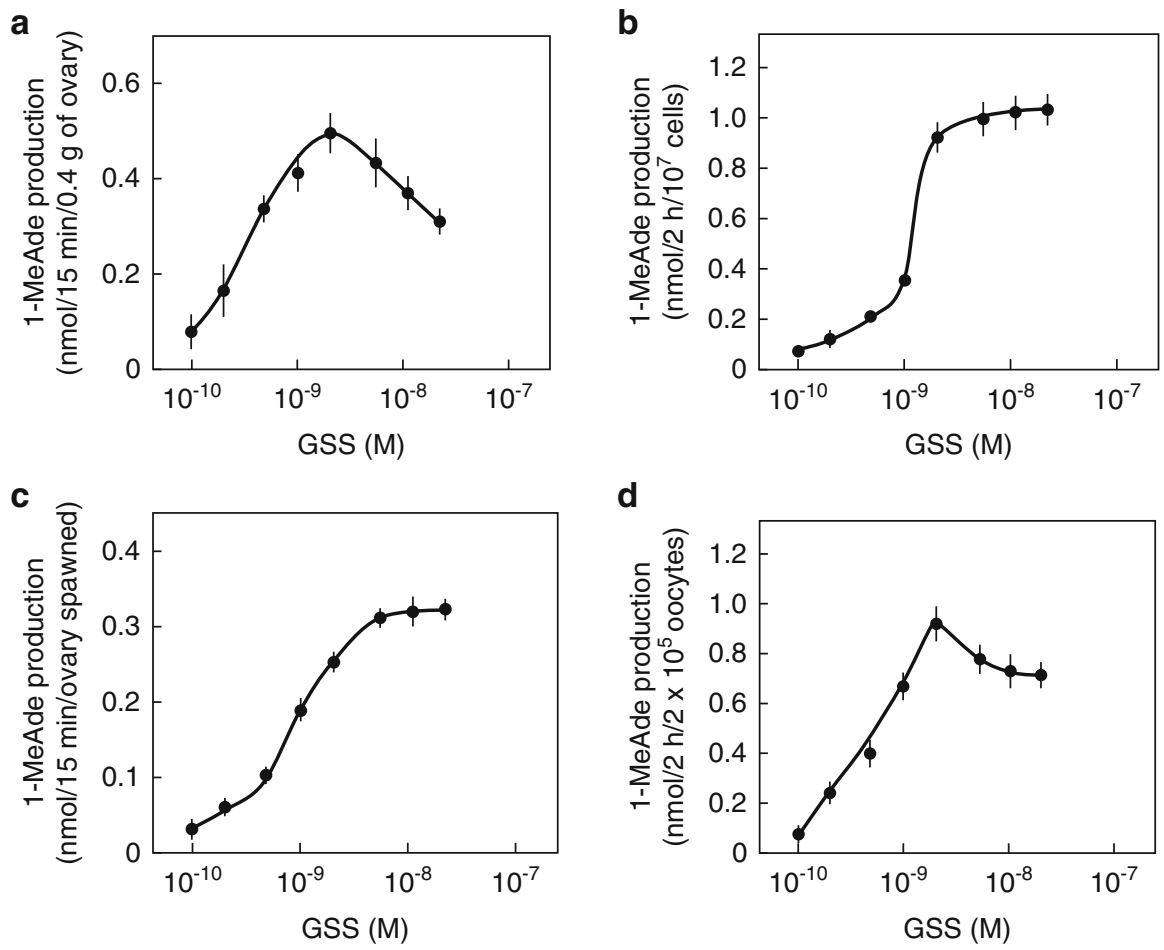

Fig. 10.2 Effect of GSS on 1-methyladenine (1-MeAde) production by an ovarian fragment (a), isolated follicle cells (b), folliculated oocytes (c), and spawned ovary (d) of starfish A. pectinifera. After incubation in ASW at $20^{\circ} \mathrm{C}$ containing GSS at concentrations as indicated, 1-MeAde concentration was determined by biological assay. Values are mean \pm SEM of four separate assays using different animals

concentrations, 1-MeAde was produced in the incubation medium (Fig. 10.2c). The production of 1-MeAde was markedly dependent on GSS concentration. A decline in 1-MeAde production was not observed at a high concentration of GSS, in agreement with the result obtained in isolated follicle cells. Thus, effects of a high concentration of GSS on 1-MeAde production in the spawned ovaries are different from those in the intact ovaries. To elucidate this, we used folliculated oocytes to examine GSS action on 1-MeAde production. The folliculated oocytes were prepared as described previously (Mita 1985). GSS stimulated 1-MeAde production in folliculated oocytes (Fig. 10.2d). The amount of 1-MeAde produced by folliculated oocytes increased in a dose-dependent manner of GSS, but it decreased slightly at a high concentration of GSS. This result suggests that oocytes or other related matter disrupt 1-MeAde production in follicle cells.

On the other hand, it has been shown that L-glutamate inhibits GSS-induced spawning in A. pectinifera (Ikegami et al. 1967). Thus, we examined the effect of L-glutamate on GSS-induced 1-MeAde production in follicle cells. When isolated follicle cells were incubated with GSS at concentrations of 2 and $20 \mathrm{nM}$ in the 
Fig. 10.3 Cross sections of ovary in starfish A. pectinifera. (a) Light micrograph shows folliculated oocytes. Bar $50 \mu \mathrm{m}$. Association of follicle cells with oocyte (b) was observed by ultramicroscopy. Bars $1 \mathrm{~mm}$. $C t$ cortex, EJ egg jelly, $F c$ follicle cells, $G V$ germinal vesicle, $O c$ oocyte
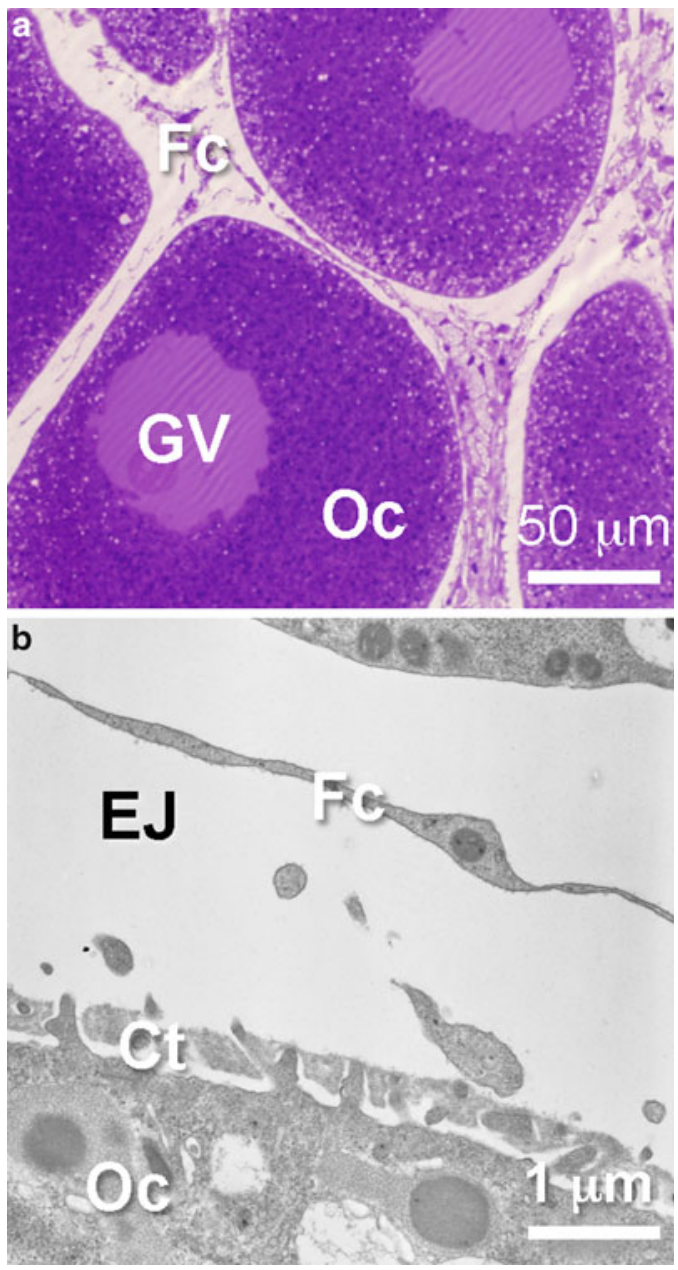

absence or presence of $10 \mathrm{mM} \mathrm{L-glutamate,} \mathrm{1-MeAde} \mathrm{production} \mathrm{occurred} \mathrm{regardless}$ of presence of L-glutamate (Table 10.1). This result suggests that L-glutamate has no effect on GSS-induced 1-MeAde production in follicle cells.

\subsection{Effect of Egg Jelly on GSS-Induced 1-MeAde Production}

Although the follicle cells are covered with the oocyte surface (Fig. 10.3a), there is an interspace between the follicular envelope and oocyte surface (Fig. 10.3b). It has been shown that egg jelly is distributed in this interspace (Shirai et al. 1981). Thus, we examined whether the egg jelly affects GSS-induced 1-MeAde production by follicle cells. 
Table 10.1 Effect of L-glutamate on gonad-stimulating substance (GSS)-induced 1-methyladenine (1-MeAde) production in isolated follicle cells of the starfish Asterina pectinifera

\begin{tabular}{ll}
\hline Condition & $\begin{array}{l}\text { 1-MeAde production } \\
\left.\text { (nmoles } / 2 \mathrm{~h} / 10^{7} \text { cells }\right)\end{array}$ \\
\hline Control & $\begin{array}{l}\text { Undetectable } \\
\text { L-Glutamate }(10 \mathrm{mM})\end{array}$ \\
GSS $(2 \mathrm{nM})$ & $0.92 \pm 0.11$ \\
GSS $(20 \mathrm{nM})$ & $1.08 \pm 0.17$ \\
GSS $(2 \mathrm{nM})+$ L-glutamate $(10 \mathrm{mM})$ & $0.88 \pm 0.15$ \\
GSS $(20 \mathrm{nM})+$ L-glutamate $(10 \mathrm{mM})$ & $0.98 \pm 0.15$ \\
\hline
\end{tabular}

After $2 \mathrm{~h}$ incubation of follicle cells with 2 or $10 \mathrm{nM}$ GSS in the absence or presence of $10 \mathrm{mM}$ L-glutamate, 1-MeAde concentration was determined by biological assay Values are mean \pm SEM of three separate assays using different animals

Fig. 10.4 Effect of egg jelly on GSS-induced 1-MeAde production by isolated follicle cells in starfish A. pectinifera. After $2 \mathrm{~h}$ incubation at $20^{\circ} \mathrm{C}$ with $10 \mathrm{nM}$ GSS in the presence of egg jelly at concentrations indicated, 1-MeAde concentration was determined by biological assay. Values are mean \pm SEM of three separate assays using different animals

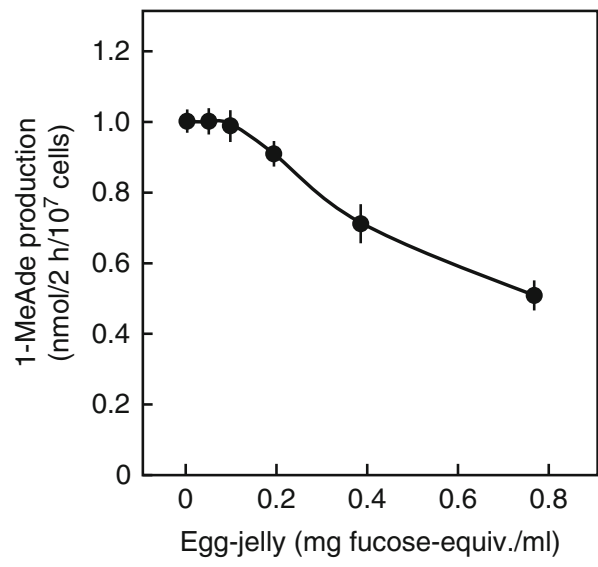

Egg jelly was prepared by acidifying a $20 \%$ defolliculated oocyte suspension in ASW with $\mathrm{HCl}$ to $\mathrm{pH} 5.5$ for 4-5 min. The oocytes were removed by centrifugation at $500 \mathrm{~g}$ for $5 \mathrm{~min}$, and the supernatant was adjusted to $\mathrm{pH} 8.2$ with $\mathrm{NaOH}$. Undissolved matter was removed by centrifugation at $10,000 \mathrm{~g}$ for $30 \mathrm{~min}$ at $4{ }^{\circ} \mathrm{C}$. The concentration of eggjelly solution was estimated by carbohydrate determination using the method of Dische and Shettles (1951) with D-fucose as the standard. When isolated follicle cells were incubation with $10 \mathrm{nM}$ GSS in the presence of egg jelly at various concentrations, 1-MeAde production decreased gradually as the egg-jelly concentration was raised (Fig. 10.4), suggesting that the egg jelly inhibits GSS-induced 1-MeAde production in follicle cells. The decrease in 1-MeAde production at a high concentration of GSS may be caused by the egg jelly. However, it is unexpected that egg jelly has an inhibitory effect on GSS action to stimulate 1-MeAde production within the ovaries. It has also been shown that egg jelly acts directly to induce contraction of the ovarian walls (Shirai et al. 1981). Further studies on ovarian wall contraction should provide useful insights into the hormonal control of ovulation and spawning of starfish. 


\subsection{Conclusion}

1. The oocytes released from ovaries of starfish Asterina (A.) pectinifera were induced by GSS in a dose-dependent manner.

2. However, a high concentration of GSS failed to induce the spawning.

3. 1-MeAde production by ovarian fragments declined at a high concentration of GSS.

4. Similar dual effects of GSS were observed in folliculated oocytes, whereas 1-MeAde production in isolated follicle cells and spawned ovaries did not decrease at a high concentration of GSS.

5. Because egg jelly inhibited GSS-induced 1-MeAde production in follicle cells, it may be possible that the egg jelly disturbs GSS action on 1-MeAde production and spawning in ovaries.

Open Access: This article is distributed under the terms of the Creative Commons Attribution Noncommercial License which permits any noncommercial use, distribution, and reproduction in any medium, provided the original author(s) and source are credited.

\section{References}

Cheat AB (1966a) Neurochemical control of gamete release in starfish. Biol Bull 130:43-58

Cheat AB (1966b) The gamete shedding substance of starfishes: a physiological-biochemical study. Am Zool 6:263-271

Dische Z, Shettles LB (1951) A new spectrophotometric test for the detection of methyl pentose. J Biol Chem 192:579-582

Hirai S, Kanatani H (1971) Site of production of meiosis-inducing substance in ovary of starfish. Exp Cell Res 57:224-227

Hirai S, Chida K, Kanatani H (1973) Role of follicle cells in maturation of starfish oocytes. Dev. Growth \& Differ 15:21-31

Hiraoka D, Hori-Oshima S, Fukuhara T, Tachibana K, Okumura E, Kishimoto T (2004) PDK1 is required for the hormonal signaling pathway leading to meiotic resumption in starfish oocytes. Dev Biol 276:330-336

Ikegami S, Tamura S, Kanatani H (1967) Starfish gonad: Action and chemical identification of spawning inhibitor. Science 158:1052-1053

Kanatani H, Shirai H (1969) Mechanism of starfish spawning. II. Some aspects of action of a neural substance obtained from radial nerve. Biol Bull 137:297-311

Kanatani H, Shirai H, Nakanishi K, Kurokawa T (1969) Isolation and identification of meiosisinducing substance in starfish, Asterias amurensis. Nature (Lond) 221:273-274

Kanatani H, Shirai H (1970) Mechanism of starfish spawning. III. Properties and action of meiosisinducing substance produced in gonad under influence of gonad-stimulating substance. Dev Growth Differ 12:119-140

Kanatani H (1985) Oocyte growth and maturation in starfish. In: Metz CB, Monroy A (eds) Biology of fertilization, vol 1. Academic, New York, pp 119-140

Kishimoto T, Kanatani H (1976) Cytoplasmic factor responsible for germinal vesicle breakdown meiotic maturation in starfish oocyte. Nature (Lond) 260:321-322

Kishimoto T, Usui N, Kanatani H (1984) Breakdown of starfish ovarian follicle induced by maturation-promoting factor. Dev Biol 101:28-34 
Mita M (1985) Effect of cysteine and its derivatives on 1-methyladenine production by starfish follicle cells. Dev Growth Differ 27:563-572

Mita M, Ueta N, Nagahama Y (1987) Regulatory functions of cyclic adenosine 3',5'-monophosphate in 1-methyladenine production by starfish follicle cells. Biochem Biophys Res Commun 147(1):8-12

Mita M, Nakamura M (1994) Influence of gonad-stimulating substance on 1-methyladenine level responsible for germinal vesicle breakdown and spawning in the starfish Asterina pectinifera. J Exp Zool 269:140-145

Mita M, Yoshikuni M, Ohno K, Shibata Y, Paul-Prasanth B, Pichayawasin S, Isobe M, Nagahama Y (2009) A relaxin-like peptide purified from radial nerves induces oocyte maturation and ovulation in the starfish, Asterina pectinifera. Proc Natl Acad Sci USA 106:9507-9512

Mita M, Yamamoto K, Nagahama Y (2011) Interaction of relaxin-like gonad-stimulating substance with ovarian follicle cells of the starfish Asterina pectinifera. Zoolog Sci 28:764-769

Okumura E, Fukuhara T, Yoshida H, Hanada Si S, Kozutsumi R, Mori M, Tachibana K, Kishimoto $\mathrm{T}$ (2002) Akt inhibits Myt1 in the signaling pathway that leads to meiotic G2/M-phase transition. Nat Cell Biol 4:111-116

Shirai H, Yoshimoto Y, Kanatani H (1981) Mechanism of starfish spawning. IV. Tension generation in the ovarian wall by 1-methyladenine at the time of spawning. Biol Bull 161:172-179

Tadenuma H, Takahashi K, Chiba K, Hoshi M, Katada T (1992) Properties of 1-methyladenine receptors in starfish oocyte membranes: involvement of pertussis toxin-sensitive GTP-binding protein in the receptor-mediated signal transduction. Biochem Biophys Res Commun 186: $114-121$

Yoshikuni M, Ishikawa K, Isobe M, Goto T, Nagahama Y (1988) Characterization of 1-methyladenine binding in starfish oocyte corties. Proc Natl Acad Sci USA 85:1874-1877 